\title{
NEW INTERDISCIPLINARY ASPECTS ON SCIENCE FOR CONSERVATION OF CULTURAL HERITAGE-I
}

\author{
Sandu, I. C. A. ${ }^{1} \&$ Sandu, I. ${ }^{2}$ \\ ${ }^{1}$ Requimte e Núcleo do Departamento de Conservação e Restauro, Faculdade de Ciencias e Tecnologia, \\ Universidade Nova de Lisboa, Campus da Caparica, 2829-516 Caparica, Portugal \\ ${ }^{2}$ Laboratory of the Scientific Investigation and Conservation Cultural Heritage, \\ ARHEOINVEST Interdisciplinary Platform, Alexandru Ioan Cuza University of Iaşi, \\ Blvd. Carol I, no. 11, 700506, Iaşi, Romania \\ E-mail:ion.sandu@uaic.ro
}

\begin{abstract}
The paper is the first note presenting a series of modern aspects regarding the interdisciplinary of the science for conservation of the cultural heritage, as personal contribution to the field. Thus are presented in the light of a new vision on the definitions, concepts and specific terms, lucrative sub-domains with their objectives and activities, liberal professions in the field of the cultural heritage, the elements and patrimonial functions, the conservation levels and their priorities.
\end{abstract}

Keywords: Conservation science, Nomenclature, Liberal professions, Elements and patrimonial functions, Conservation levels and priorities.

\section{Introduction}

In the current global geopolitical situation, the history and cultural legacy of a nation represents their identity document. Preserving and transmitting their authentic, tamper-proof form to future generations is a very important approach that stands in front of any government, a permanent concern of assessment and upgrading of the images of the past. As an interdisciplinary field, the scientific conservation of the cultural heritage represents much more than a related discipline, is a complex system of standards and measures, coherent policies to promote and value through entry in the world heritage circuit, a discipline called the science of conservation [1]. Both
UNESCO and various academic institutions and NGOs from different countries, some having international activities, support national policies of valuing the cultural heritage. The science of conservation issue, as related domain, caught the attention of many Universities and Research Institutions. Thereby in 1996 the Polytechnic University of Valencia, founded the Forum UNESCO "University and Cultural Heritage", which in a short time drew over 260 universities with specialized departments of Cultural Heritage. Every year, this Forum organizes in different academic centers around the world meetings on scientific conservation, where different cases of the 
conservation state are presented together with various experiences of young and recognized groups and the guidelines concerning the management, the valuing of the cultural heritage by various activities focused on discovery, acquisition, investigation, evaluation, preservation and museum display [2]. Things have evolved so much that we ended up organizing master classes and inter-university $\mathrm{PhDs}$ - across borders in the field. Among others is to be mentioned the European Doctoral School EPISCON, headquartered in the University of Studies in Bologna (Italy), which was formed by 12 European Universities with tradition and finalized the doctoral thesis of 16 young researchers from different countries in the world [3] [4]. Every year there are organized roundtables, meetings and workshops, in which the interdisciplinary current issues of the scientific conservation are being discussed. For example, to the next Conservation Science ICCEROM Forum, which will be held in Rome between 16 and 18 October 2013, 60 experts in different fields and areas of cultural heritage will discuss mutual interactions between sciences and the conservation of the cultural heritage, the influence of research and scientific investigation of preservation and restoration processes, the displaying of the monuments and mobile artifacts and other perspective aspects. This event is held by a consortium of 16 organizers which joined the ICCROM for debating the actual problems and to reflect on future directions for development as a freestanding science with the help of all the others fields. The Forum invites to discussions other leading researchers with substantial contributions to the domain [5]. One of the current issues that arise for the researchers in such events has highlighted the relevance of Conservation Science as a discipline-related, for a wide range of social priorities, analyzed through its development prospects as interdisciplinary science. Special attention is paid to the impact of science on the conservation of cultural and natural heritage, through their role in the harnessing by means of a high level structural-functional, ambiental and cultural reintegration [6] [7]. In this respect, on the basis of previous experiences developed by the author in the field, there are presented a number of issues that stand in the face of modern universities and institutions, offering a fresh approach to the notions of the terminology definitions, concepts and terms in the field, as well as differentiated presentation of lucrative areas, with their objectives and activities, patrimonail elements and functions, levels of conservation and their priorities, routes travelled by the artifacts, their representative contexts, types of expertise and their role etc.

\section{Nomenclature of the Science for Conservation}

An uniform terminology and a guiding theory for the activities of integrated scientific conservation of the cultural heritage represents an important goal both national and global. Even if it exists a constant concern for the elaboration of some principles and general acceptable terms, the results at global level were many times contradictory and disputed [8] [9] [10] [11]. Immediately after the floods of the river Arno over Firenze in 1966, when worldwide specialists fought to save the affected monuments, there was more and more felt the need of elaboration of principles, norms and terminologies unanimously accepted. Although as early as 1964 in Venice was published the first code of ethics of conservation [12], only after 1975 were first advanced proposals for the basic terms used in the field and the fundamental principles that govern the work of conservation, according to the national specific [13] [14] [15] [16], some of them beeing edited in the last years [17] [18] [19] [20]. In time, there were developed many codes of ethics, the most recent beeing that from Krakow in 
2002, where some terminology harmonization issues are discussed by taking proper definitions and terms form exact sciences. After year 2000, the problem of acceptance the nomenclature for the domain using the terms from related sciences became more urgent by editing monographies which presents critically current definitions, starting with the base terms, often used to the new ones from other languages as neologisms [21] [22] [23] [24] [25]. The system crises in recent years contributed to the increasing complexity of problems faced by experts in the field that led to the development of specialized higher education in each country and fundamental research which imposed the introduction of modern terminology. Thereby, conservation science has become a related discipline, well established with a specific nomenclature, by taking from the interdisciplinary system the correct and consistent terms, definitions, notations, codes etc. Even the most commonly used term "conservation", has different meanings and is used loosely, although in most European countries is attributed to the complex set of activities applied separately, sequentially or not, for valuing cultural heritage assets and those of nature. Instead, the Anglo-Saxons used the term with a general sense including the two different fundamental activities: preservation and restoration. Currently in many European countries there are still used, instead of the correct "preservationrestoration", the terms "conservation restoration", which have completely different meanings: conservation is the general term with the sense of preserving cultural heritage, which relates to a certain level of conservation level (represented by \%); preservation means the two-directions - preventive or environment control and prophylactic or treatments to stop the evolutionary effects of deterioration and degradation, while restoration refers to the lucrative steps, with specific activities which relate differently to the nature of the material, the physical condition of the structural element, working technique, on methods of intervention and other ones. Conservation, in the modern meaning, is a generic term for the science of conservation and represents a series of measures, tools and actions that cover all activities aimed at keeping unaltered the layout of heritage (and message sent), as close to the original, in the continue recovery process, social integrated and with preservation of historical stratification (the traces left by certain significant events) having in the alternative, along with the preservation and restoration demarches, also those of safety and protection. It's totally wrong the use of the term "conservation" in the sense of preservation and protection respectively. There are also known other terms with broad sense, such: the notion of monument, expressing a temporal dimension and representing in terms of typology, number and value, certain traits of a society specific features, accumulation and economic development, political stability, level of creation and cultural dialogue. Referring to the preservation and restoration of historical monuments, The Venice Cartae gave already since 1964 a broader sense to the notion of monument, as a consequence of urban offensive and systematization, enhancing it by introducing the concepts "urban reserve", "old urban core", "old suburban area", "cultural and natural protection area" and others. In this sense the expression "historic monument" includes the isolated architectural creation and also the urban or rural settlement that brings the testimony of a particular civilization, significant changes or of an historic event, taking into account both great creations and modest works that have gained great cultural significance over time. There are also other terms that are used improperly such as deterioration and degradation, which are assigned the same meaning and are actually quite different notions, which imposed strict definitions. In general, when considering conservation status [26], research take into account or in relation to the two groups of effects: deterioration, which changes the physical state of a structural element or 
functional element with micro- or macroscopic destructions under the action of physical, mechanical and climatic factors (by example the breakage of a construction beams or frame of a painting, the cracking of a painting layer or masonry, plaster peeling off, tearing paper support or of the of the fabric substrate, expansion or shrinkage of the wooden panel etc.) and degradation, that by alteration changes the chemical nature of a material under the action of chemical, radiating out and biological agents, co-assisted or not by the climatic factors (by example, the corrosion of metals; rotting wood, paper, leather/parchment, and textile, pigment discoloration; opacifying of the obsidian glass or gemstones, efflorescent and deliquescent salts and so on). It is known that degradation takes place from outside to inside the material, while deterioration evolves from the minimal resistance points (e.g., points with natural or manufacturing defects) in any direction, especially those with minimal structural stability. In general, degradation is a cumulative effect of several factors or agents, in turn, deterioration occurs as a result of the action of a single factor or agent. To not generalize the case, we mention that there are cumulative deteriorations, such as shrinking with longitudinal-radial and circular cracking (regarding the annual rings), and the split of the plug-bolts from wood, under the influence of concomitant or sequential temperature, humidity and mechanical tensions [27]. Deterioration can always be described by planimetric transformation schemes, topographic or stratigraphic on micro- or macro structural level, while degradation is presented by sequences of chemical reactions or chemical interactions, electrochemical, radiochemical / thermo chemical or biochemical, taking place at the molecular level (nanostructure) and supramolecular (microstructure) [27]. There are known a number of cases where the two effects occur either simultaneously or consecutively, the mechanism of their development being very difficult to reveal. For example, wood attack by fungus Merullius lacrimans leads to alteration of both cellulose and lignin, translated by weakening and rotting wood (degradation effects), followed by cracking of the affected party (deterioration effects), so the biodegradation has as a side effect the biodeterioration too. Similarly, the attack of the xylophage insects by creating flight holes and galleries in wood, leads to physical deterioration and by the products of metabolism and induced enzyme systems leads to an evolving embrittlement of the wood. This is a case of biodegradation coupled with biodeterioration [6] [27]. The need of differentiated use of the two terms appears also on the background of the appearance of the periodical International Biodeterioration and Biodegradation, the official scientific journal of the Society, published since 1978 eight times a year by Elsevier Press and organizing since 1995 the International Biodeterioration and Biodegradation Symposium. There are many discussions on how to use in the conservation practice of monuments and other civil engineering heritage, the terms of restoration and rehabilitation, which are taken for each another or wrong attributed, the first referring to reintegration of a structural system, polychrome or environmental and the second to the repairing or restoration of a functional system. Restorers don't conceive to make use of the concept of rehabilitation, an unjustified opportunity when we refer to the restoration of functional systems (e.g., rehabilitation of heating systems, lighting or sewage of a monument) [21] [22] [23] [24] [25]. Another example is that of the notion of using a technique or a method, first being an operating system (device), achieved using an analytical method, study, exam, test, examination or investigation, describing a methodology or one experimental approach, used as a tool of integrated science, disciplines etc. Often these terms are used incorrectly, in place of the process or technology, the latter 
representing "a logical sequence of steps or stages of work characterized by their order of development, by the initial conditions and the final products or results" [28] [29] [30] [31] [32] [33] [34]. Also, in the curricula of some university departments of conservation, we find the discipline Artistic techniques and manufacturing technology that is named incorrectly. Just the notion of an artistic technique, which is known in some languages, may be used in this formulation, however the technologies of making the artwork, cannot be called art. An expression often used incorrectly is that of relative humidity, which is very often discussed as an exogenous factor, together with absolute humidity, expressing both the atmospheric humidity, an environmental factor. When discussing the influence of atmospheric humidity of systems, the notion of relative humidity should not be used as a determining factor. Even in the graphics, at explaining the ordinate or the abscissa, where it has to be put the factor or parameter, will be written: atmospheric humidity or the environment humidity, followed by a \%RH after the comma for relative humidity, or $\mathrm{g}_{\text {water vapors }} / \mathrm{m}^{3}$ air, $\mathrm{UA}$ ( $\left.\mathrm{g}_{\text {water vapors }} / \mathrm{kg}_{\text {air }}, \mathrm{UA}\right)$, whether expressed in absolute humidity [35]. Another example is related to the plural term component, which has two forms of expression, often used incorrectly: components, which means a part of a whole, as a chemical congruent, (solution components, materials etc.) while parts are physical pieces of a whole, which are linked or interconnected, regardless of their nature (parts of a monument or of a circuit etc.) [35]. The list of examples could go on, but this paper has to become just a signal for corrections. It is very important to use a common language at the international events. We conclude by explaining other three groups of terms: * Adsorption and absorption, use properly only by chemists and physicists, working in conservation science, and assigning different meanings: adsorption - physical process of surface involving physical links and absorption * Chemical process of dissolution/solubilization at the molecular level, to the volume faze of a system/material (for the last are known some assignments accepted such as: spectral absorption, vibration absorption and sound in a material/body etc.). * Calamity or cataclysm, caused by natural factors and catastrophe or disaster caused by anthropogenic factors, the last group of terms being used as an attribute or metaphorically at random. * Viability, assigned within living systems and fiability for material systems and technological systems in vitro, often the two terms are also used incorrectly.

\section{Lucrative subfields of Conservation Science}

As we know, science conservation includes a number of working areas with specific activities [21] [22] [23] [24] [25], as: * Discovery, acquisition or transfer (as appropriate). * Classification as categorizing or sorting/classification value as value ranking and typological grouping (by material, artistic technique, conservation status etc.). * Scientific investigation and research done by involving various surveys, studies and analyzes requested or imposed by the circumstances. * Passive or preventive preservation (creating optimal conditions for storing by climatization), when acting on the environment. * Curative preservation or prophylactic treatment, by stopping evolutionary effects of deterioration and degradation by acting directly on the object (biocide treatments, moisture and chromatic stabilization, fireproofing the organic materials, strengthening the foundation soil and embankment to stop landslides etc.). * Restoration by consolidation interventions and structural-functional reintegration (additions), aesthetic and chromatic reintegration (through techniques: mimetic, tratteggio, puntillisimo etc.), environmental reintegration (landscape, architecture, urban etc.). * Displaying and introduction in the museum circuit (monitoring the curative preservation and restoration interventions made recently, 
performed for a preset time or regular monitoring - current conservation status throughout the period of storage and display). * Hoarding and valuing (for museum or touristic purposes), dissemination (through print, web, video etc..), and cultural reintegration (diplomacy - building economic bridges: integrating cultural diplomacy into nation branding, corporate social responsibility and global governance). * Protection (guarding against theft, vandalism, fire and disasters) maintenance (cleaning, cooling, lighting etc.) and public presentation. Valuing, harnessing and hoarding are cultural heritage means to emphasize the value of an artwork, movable or immovable.

\section{Professions in the Cultural Heritage field}

By considerations regarding the artifact trade and for their protection and valorisation, by order of the Ministry of Culture, all auction houses, galleries, bookshops and places that sell art (only in Bucharest exist more than 200), must hire an expert qualified by the Ministry. In our country there are almost 600 certified experts. From them, almoust 160 are certified for paintings, each one with his own specialisation on a certain type of painting or on groups of artists and periods. For this reason, the experts certified for the XIXth century paintings must appreciate besides, the contemporary art or other artifacts such as tapestry, furniture, crystals, pottery etc. They are well paid by the people interessed on selling the merchandise. In Western Europe, the buyer comes with his own expert. In this conditions, a new fenomenon appears, because of the untrained personal in galleries and antiques shops, some of them becoming corrupt. Once Romania joined the EU, a new set of chaotic laws and normatives appeared, with an unspecified Heritage Fund or not fully indexed, for which were needed more certified specialists. Here, there is no ,art experts" institution. From the National Craft terminology are missing many field dedicated words for Conservation Science of the Cultural Heritage. At this time, in Europe, the need for two levels: first level specialisation by Masters which gives the Specialist Certificate with free practice for every EU country, and the second level Ph.D. which allows beside the titulature of „Doctor" or $\mathrm{PhD}$ in a field linked to Environemental Science, Materials Science/Engineering, Law (regarding Cultural and Intelectual Property) or History/Archaeology, patrimonial goods and archeological artifacts, the Expert Certificate with free practice to be obtained. Based on these specilisations, following crafts can be obtained: * Scientific preservator, with the titulature doctor or $\mathrm{PhD}$ of science, who can cover any of the Conservation Science (acquisition, classification, investigation, preservation, restoration, display etc.), with the highest expert level, able to become a cultural manager, counselor or cultural institutions administrator. * Scientific investigator, who is focused on the five groups of expertise (authentication, patrimonial evaluation, determination of conservation state, compatible interventions, monitoring the behavior for a specified period, monitoring the conservation state of the entire display and storing period), with two specialization levels, the base one as specialist with a Masters degree and the expert obtained after PhD. * Art historian is a job occupied by college graduates of Art History and Theory and History, who can be a free practice specialist, museographer, guide or curator, after a postgraduate profile specialization, or art expert after doctoral certification. * Archaeologist is a History graduate, the two professional levels specialist or expert, who is dealing with identifying, investigating/researching and managing archaeological sites and recovered artifacts. * Curator has in his attention the protection and preservation activities (passive or active climatization and preventive or prophylactic treatments to halt the evolutive effects of damage or degradation), also with two levels of specialization, the specialist as base promoted by Masters and the superior as expert obtained after $\mathrm{PhD} *$ Restorer applies the preventive and prophylactic activities through consolidation, stabilization and structural reintegration, 
esthetic/cromatic reintegration (mimetic, trategio, puntilisimo etc.), environmental reintegration (landscape, architecture) and cultural reintegration in this case the two levels of specialization, specialist as base to be promoted by Master and expert certification obtained after $\mathrm{PhD}$. * Museographer is the curators complementary job, that in addition to the basic activity, it may cover the activities of the trustee and even the guides, with one of the two levels of specialization at the base as a specialist, promoted by Master and

\section{Patrimonial Elements and Functions}

In evaluating cultural heritage artwork are taken into consideration the characteristic elements of individualization and the patrimonial functions. First, known as patrimonial elements, come mostly from the process of making the artwork, only some being acquired over time and gradually increasing in patrimonial value, while patrimonial functions are acquired over time. Patrimonial items are grouped by five criteria related to: * design/creation/conceiving (material, technical art, process of making the artwork/manufacturing technology); paternity (author/pupil, school, workshop, process of making the artwork/manufacturing technology and usage, owner, custodian, instead of displaying/storing etc.); * age (dating, patina, conservation status, time of putting in work, display in the museum, the background of the artifacts, purchase, transfer, substitution/theft etc.); * value share (group or level of classification, catalog number, exchange or market share, valuing/cost of sale/purchase); * degree of rarity and the heritage impact. Between the features of the heritage individualization, in valuing, an important role is held by: design, material, artistic technique, process of making the artwork (structuralfunctional features, size/dimensions, technological complexity, novelty etc.) age/time patina and conservation status (perfect/not run or moved, very good, good, poor or very poor). Time patina or historic mark, as primary or noble patina from the period of making and usage, secondary or low patina during abandonment, and expert certification obtained after $\mathrm{PhD}$. * Guide is the job occupied by graduates in History and History of Art and Theory, with a lead role in explaining to the public/tourists the property and values of the displayed data in museum, usually having only the specialist level. Scientific investigator with traditional art historian and archaeologist may occupy art expert status, who can serve evaluation in galleries, antique shops and consignments or may occupy jobs of superior advisors for cultural institutions. tertiary or contamination patina during the laying period in the archaeological site), along with age (prehistoric, antique, medieval, modern, current), exponentially increase the share value of an artifact. The degree of rarity (unique/invaluable, very rare, rare, common), originality, and unique attributes, copy or series, are also important elements used in valuing or establishing the classification group and the value shares by evaluation grids. Regarding patrimonial functions, only one is taken into consideration from the process of making the artwork, the artistic or aesthetic function, while the other four are obtained in time, as follows: * historicaldocumentary function, given by historiographical data, offered by written documents, photographs, drawings or directly on the object by investigating the inscriptions, fingerprints, decoration, interventions in post-work, or other characteristics related to work contexts, commissioning, operation, abandonment, the discovery and so on); * technicalscientific function, given by the material, artistic technique, the process of making the artwork, its goal and use, and preservation-restoration interventions; * socio-economic and urban-administrative function, which is closely related to acquisitions/transfers, share value at displaying, the role and the place occupied in the social, political and economic context along time, and the current uses, monuments with utility functions (offices) or collections ; * spiritual function, the highest, given by the impact that it had and has in opening new patrimonial system 
(works founded new styles, techniques, technologies etc.) or commensurate by the role and contributions in the development of society (discoveries / inventions, new

\section{Conservation Levels}

Valuing by museum display and making new studies for the cultural heritage means full use of the patrimonial elements and functions [35] [36] [37] [40] [42]. In displaying an artifact, there must be valued as many of the patrimonial elements (authenticity, authorship, catalogue value share of stock or market/appreciation, level/group classification and ranking, age/patina time) and some of its interest functions (either the artistic, aesthetic or historical or scientific-technical documentation). The capitalization of the artifact aims to increase the asset value. On the first hand it is focused on new data (information, structural and functional changes, gifts or grants unknown, documents, photographs, maps and other unusual things, unpublished), and on the other hand editing web pages, albums, organizing round tables, conferences, symposiums, conducting educational itineraries (open lessons, interactive etc.) involvement of new modern display systems (static or dynamic dioramas, holograms etc.) and organizing/arranging in museum exhibitions and so on. A very important aspect of valorization is the involvement of valuing goods in teaching at all educational levels and protocol systems by presenting elements of authenticity, national representation etc. For an optimal valorization [20] [25] [35] [36] [37] [38] it is required a good knowledge of the patrimonial functions acquired in time, beside of the conservation status, that allow assignment to a particular classification level, with priority interventions related to the active preservation and restoration, and display conditions. Also, for a good enhancement, conditions to display or storage must comply with the standards of protection. In order to achieve an integrated conservation of mobile cultural theories/concepts and mechanisms / effects / phenomena), for objects with cultic or liturgical value and the theological, dogmatic function.

heritage assets from collections, differentiated by degree of conservation, recent studies [20] [25] [35] [39] [40] have highlighted the importance of their group on five levels of conservation, which requires measures, means and actions targeting preservation and restoration interventions, protection and preservation of their best. In establishing these levels, besides age and state of preservation, there must be taken into consideration also the value and rarity of the artifact. For example, we present the case of the numismatic pieces whose diversity in terms of material composition, age, rarity and cases of conservation status, are very interesting artifacts, often captured for research, being very attractive to public and collections. Level I includes pieces with great heritage value that have poor conservation status, so does not allow display, and there are held in storage. These require urgent intervention of active preservation (storage in environments similar to those of laying in the archaeological site or strengthen systems) not to go into irreversible collapse. This group also includes unique or very valuable pieces that do not allow the display of certain historical reasons (political), ideological, religious etc. The level has two subgroups, Closed Level $\mathbf{C L}$, fig. (1-a), which is accessible only to curators and Open Level OP, fig. (1-b), where along with curators have access the art experts, historians or documentarists, with special pass or allowance [41]. Level II includes parts of particular value, but with a relatively good state of preservation, where along with curators, various specialists have access for documentation. The artifacts can be included in the museum circuit by scientific replicas after a prior preventive or prophylactic consolidation and active preservation, fig. (2) [38]. Level III includes well-preserved 
pieces that can be displayed in museums and participate in exhibitions. They can be handled, packed and transported and the visitors can have direct access to them, fig. (3) [41]. Level IV refers to the parts well preserved, existing in large numbers in the form of surplus stock which can participate in the exchange of valuables between collections, fig. (4) [38]. Level V is the gray fund, which includes parts of irreversible

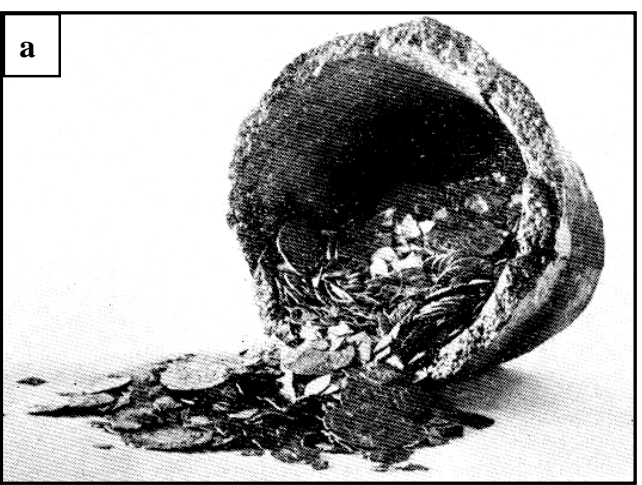

damage and decay, under collapse, with a metallic core conservation status of 15 to $30 \%$, which cannot be presented/displayed anymore, fig. (5). These parts are stored for use as teaching material in experiments. It is advisable to be held in special storage, climate conditions, not to be damaged or degraded further. Under no circumstances shall not be destroyed or removed [38].

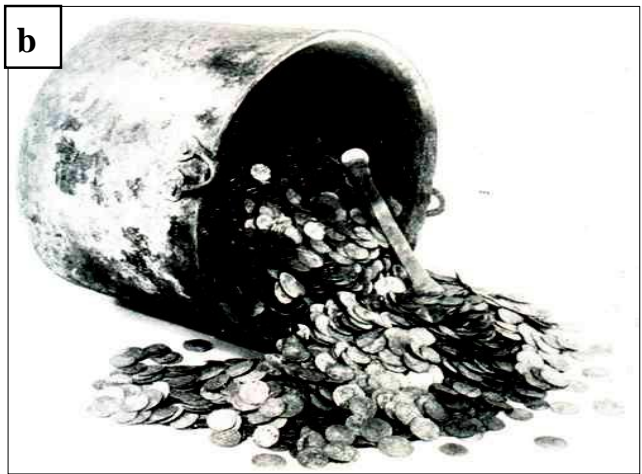

Figure (1) $\underline{\mathbf{a}}$ monetary artefact removed from the Baltic Sea water, $\underline{\mathbf{b}}$ money recovered from dried archaeological sites, where the pedological action was minimal

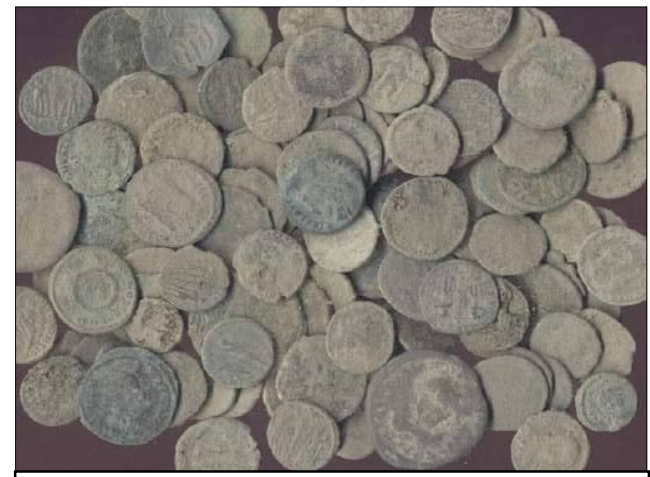

Figure (2) Coins with relatively good state of preservation, which can be displayed after preservation and restoration interventions.

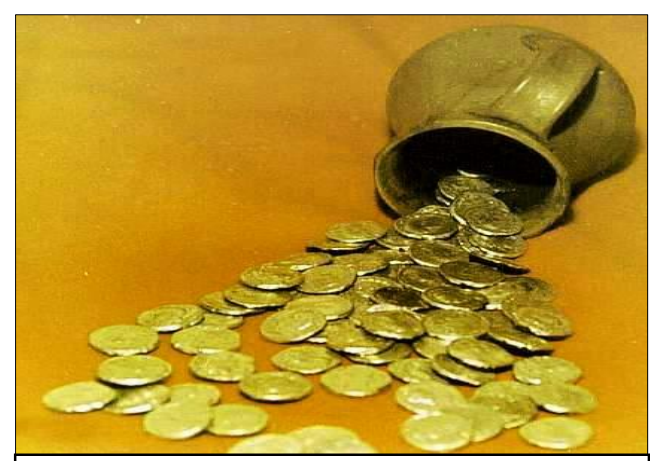

Figure (4) Gold coins in the exceptional state of preservation, in overstock from a recently discovered treasure.

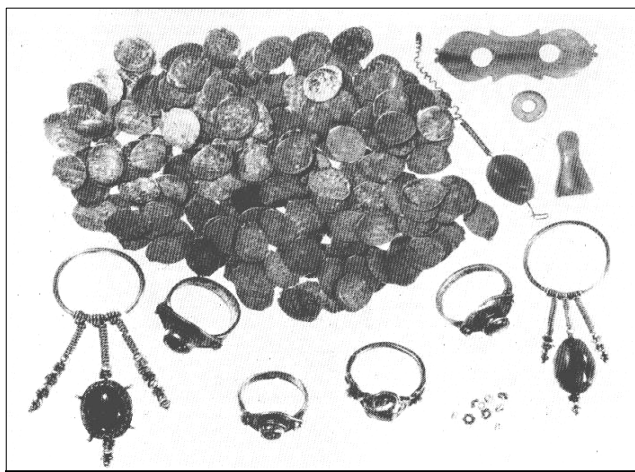

Figure (3) Silver coins and jewelry, dated 1600-1620, found at Smolensk in the Russian Federation.

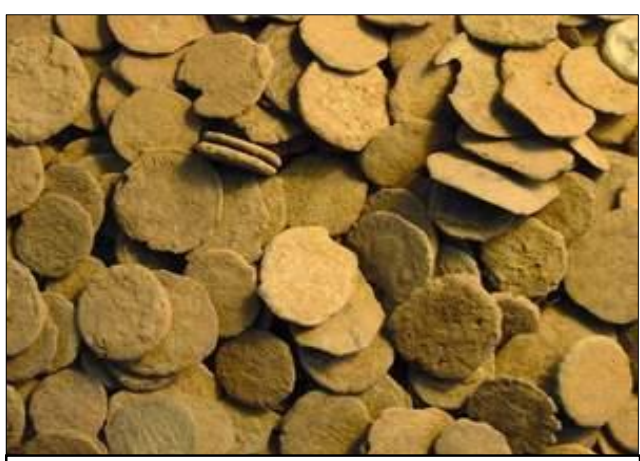

Figure (5) Bronze coins in collapse (with very thin metal core and strong thinning). 


\section{Conclusions}

Current policies in the field of Conservation of the Cultural Heritage, at any nation level, consider alongside restoration and saving the cultural heritage and their enrollment in the global values by adding them in the modern museum circuits. For a proper evaluation, the specialists in the field must be continuously informed of the latest methods used in archeological discovery, recovery and scientific investigation, the most appropriate methods of preservation, restoration and display in modern museums. In addition to the investigations and muzeum harnessing, special attention should be paid to research on the discovery of new artifacts, and solving theoretical and practical aspects related to stopping the effects of deterioration and degradation of the physical state of the materials, from various cultural assets. Then in organizing scientific meetings, workshops, trainings, exchanging experience, up to the development of academic specialization, in the three modules: license for training in the field, followed by obtaining a master's degree certificate, than the degree of specialist by doctorate (PhD) with free practice and followed by the title of Doctor in Conservation Science as an expert in this field. Academy Schools of Science Conservation should develop educational plans and curriculum for the three modules, which must be agreed in line with those of traditional schools and the credits of each course, must be transferable between schools. Improving curriculum should be closely related to the harmonization of nomenclature in the field by taking proper terminology from the other sciences. Then another very important thing is the introduction into national nomenclature of job titles in the field, on three levels: junior assistant, specialist and expert. In the light of this study, the research infrastructure is fundamental for academic schools and research institutions, museums and state institutions holding assets of Cultural Heritage (archives, libraries a.s.o.).

\section{References}

[1] Sandu, I., (2004). Nomenclature of the science for conservation of cultural heritage (Original title: Nomenclatura patrimoniului cultural), Publishing House Performantica, Iaşi, Romania.

[2] Sandu, I. \& Sandu I.G., (2005). Modern aspects on cultural heritage conservation (Original title: Aspecte moderne privind conservarea bunurilor culturale), Vol. I, Publishing House Performantica, Iaşi, Romania

[3] Sandu, I. \& Minea, A., (2006). EPISCON (European PhD in science for conservation) an Inter-University School Model, Bulletin of the Polytechnic Institute of Iaşi, Tom LII (LVI), Fasc. 5, p: 557-563.

[4] Mazzeo, R. Sandu, I. \& Sandu, I.C.A., (2006), (European $\mathrm{PhD}$ in science for conservation), the First Inter-University School, Analele stiintifice ale universitatii "Al. I. Cuza" Iaşi, Seria Teologie, Vol. 11, p: 533-541.

[5] ICCROM Forum on Conservation Science $1^{\text {st }}$ Consortium Planning Meeting, http://www.iccrom.org/eng/news_en/2012_ en/events_en/11_13forum-meetingagenda_en.pdf
[6] Sandu I.C.A., Sandu, I., Popoiu, P. \& van Saanen, A., (2001). Methodological aspects of scientific conservation of cultural heritage (Original title: Aspecte metodologice privind conservarea ştiințifică a patrimoniului cultural), Publishing House Corson, Iaşi, Romania

[7] Sandu, I., Groll, L. \& Sandu, I.C.A., (2001). Principles and terminology used in protection, prerservation and restoration of monuments, Buletinul Institutului Politehnic "Gh. Asachi" Iaşi, Seria Construcții şi Arhitectură, Tom XLVII (IL), Fasc. 5, p. 11-22.

[8] Baldini, U., (1997). Teoria del restauro e unità di metodologia, Vol. I \& II, Publishing House Nardini, Firenze, Italy.

[9] Brandi, C., (1996), Restoration Theory (original title: Teoria restaurării), Publishing House Meridiane, Bucureşti, Romania.

[10] Anom, (1981), Per una nuova edizione della carta di Venezia, ICOMOS VI, Assamblea Generale, Roma, Italy.

[11] Condemi, S., (1997). La salvaguardia dei beni culturali. Lineamenti di storia della tutela, Publishing House Istituto 
per L'Arte e il Restauro "Palazzo Spineli", Firenze, Italy.

[12] Dancu, I., (1966). Restoration of icons on wood and glass (Orginal title: Restaurarea Icoanelor pe lemn şi pe sticlă, Publishing House Meridiane, Bucureşti, Romania.

[13] Jedrzejewska, H., (1976). Ethics in conservation, Publishing House Institutet for Materialkunskap, Stokholm, Sewdserland.

[14] Manea, C., (1981), Pentru o teorie unitară de conservare-restaurare. Principii şi terminologie, Cercetări de conservare şi restaurare a patrimoniului muzeal, Publishing House Muzeul de Istorie al României, Bucureşti, Romania.

[15] Anom, (1976). Code of ethics and guidelines for practice in conservation, American Institute for Conservation of the art and Istoric work (AIC), Washington, USA.

[16] Thompson J., (ed.), (1984). Manual of Curatorship. A guide to museum practice, Butterworths, The Museum Association, Great Britain.

[17] Plenderleith, H.J. \& Werner, A., (1988). The conservation of antiquities and works of art, treatment, repair and restoration, Oxford University Press, London.

[18] Anon., (1991). The NZPCG code of ethics in New Zeeland, Directory of conservators of cultural property, The New Zeeland Professional Conservators Group Inc., Auckland, New Zeeland.

[19] Anon, (1995). Code of Ethics and Guidelines for Practice in Directory, American Institute for Conservation, Washington, USA.

[20] Sandu, I.C.A., (2000). Fundamental Principles for Theory of Conservation and Restoration, (Original title: Principii fundamentale de teoria conservarii si restaurarii), Publishing House Corson, Iasi, Romania.

[21] Sandu, I., Prodan, E., Sandu, I.C.A. \& Cudelcu, D., (1999). Aspecte privind terminologia utilizată în expertizarea operelor de artă. I.
Noțiuni privind identificarea elementelor patrimoniale şi determinarea stării de conservare, Revista Muzeelor (Bucharest), Vol. 34, pp: 11-18.

[22] Matteini, M., Sandu, I.C.A. \& Sandu, I., (2004). Peculiar aspects related to the european program LabSTECH, on materials and methods for conservation of cultural heritage, The Scientific Annals of "Al. I.Cuza" University of Iasi, Theology Serie, Vol. 9, pp: 553-572.

[23] Sandu, I., Sandu, I.C.A. \& Cojocea, B., (2004). European modern policy concerning the conservation of hystorical monuments, The Scientific Annals of "Al.I.Cuza" University of Iasi, Theology Serie, Vol. 9, pp: 573586.

[24] Sandu, I., Dima, A. \& Sandu, I.G., (2003). Tendințe actuale în investigarea şi conservarea artefactelor metalice, Buletinul Muzeului Național Militar (Bucharest), Serie nouă, Vol. 1 (1), pp: 421-432

[25] Sandu, I., Vasilache, M. \& Sandu, I.G., (2003). Politici actuale privind conservarea monumentelor, Constructions Interactions of the Environment, Pablishing House, Gh. Asachi”, Iaşi, Romania.

[26] Sandu, I., (2007). Modern aspects regarding the conservation of cultural heritage, (Original title: Aspecte moderne privind conservarea bunurilor culturale), Vol. 5, Publishing House Performantica, Iaşi, Romania.

[27] Sandu, I., (2008). Degradation and deterioration of cultural heritage (Original title: Degradarea şi deteriorarea bunurilor de patrimoniu cultural), Vol. I \& II, Publishing House, Al.I.Cuza" University of Iaşi, Romania.

[28] Anon, (1981). Guidance for conservation practice, United Kingdom Institute for conservation of historic and artistic works, London. 
[29] Anon, (1992). Problemi di restauro. Riflessioni e ricerche, Edizioni Firenze, a cura di Marco Ciatti, Italy

[30] Anon, (2002). Petit Robert, French Dictionary, Publishing House Poche, Paris.

[31] Anon, (1991). Larousse dictionaire, Publishing House Larousse, Paris.

[32] Răduleț, E., (1964). Romanian technical lexicon (Original title: Lexiconul Tehnic Român), Vol. I XIX, Ed. Tehnică, Bucureşti, Romaina.

[33] Şuşală, I. \& Bărbulescu, O., (1993). Dictionary of art. Terms of workshop (Original title: Dicționar de artă. Termeni de atelier), Publishing House Sigma, București, Romania.

[34] Anon, (1975). Romanian explanatory dictionary (Original title: Dicționarul Explicativ Român DEX), Ed. Tehnică, Bucureşti

[35] Sandu, I. \& Sandu, I.C.A., (2002). Chemistry for conservation, (Original title: Chimia Conservării), vol. I și II, Publishing House Corson, Iași, Romania.

[36] Sandu, I.C.A., Sandu, I. \& Luca, C., (2005). Modern aspects concerning Cultural heritage conservation (Original title: Aspecte moderne privind conservarea bunurilor culturale), Vol. II, Publishing House Performantica, Iaşi, Romania.
[37] Sandu, I., Sandu I.C.A., Vasilache, V. \& Geaman, M., (2006). Modern aspects concerning cultural heritage conservation (Original title: Aspecte moderne privind conservarea bunurilor culturale), Vol. IV, Publishing House Performantica, Iaşi, Romania.

[38] Sandu, I.G., Sandu, I. \& Dima, A., (2006). Modern aspects concerning cultural heritage conservation (Original title: Aspecte moderne privind conservarea bunurilor culturale), Vol. III, Publishing House Performantica, Iași, Romania.

[39] Pearson, C., (1972). The preservation of iron cannon after 200 years under the sea, Studies in Conservation, Vol.17, p: 91-110.

[40] Mourey, W., (1979). Les objects metalliques, leurs rapports avec l'environnement, leur traitement sur le chantier, memoire de maitrrise, Polycop., Aix-en-Provence.

[41] Spasskii, I., (1970). Russkaja monetnaja sistema, Publishing House Avrora, Leningrad, Russia.

[42] Sandu, I., Vasilache, V., Tencariu, F.A. \& Cotiugă, V., (2010). Scientific conservation of ceramic artifacts (Original title: Conservarea stiintifica a artefactelor ceramice),"Al.I.Cuza" University Publishing House, Iaşi, Romania. 